\title{
MOKYKLINIO AMŽIAUS VAIKŲ MITYBOS IૃPROČIŲ TYRIMAS IR VERTINIMAS
}

\author{
Roma Bartkevičiūtè $\dot{1}^{1,2}$, Gabija Bulotaitè ${ }^{1,2}$, Rimantas Stukas², Mingailè Skardžiūtè2, \\ Indrè Nakutavičiūtè ${ }^{2}$,Albertas Barzda ${ }^{1,2}$ \\ ${ }^{I}$ Sveikatos mokymo ir ligu prevencijos centras, \\ ${ }^{2}$ Vilniaus universiteto Medicinos fakulteto Sveikatos mokslu institutas
}

Raktažodžiai: mokyklinio amžiaus vaikai, mitybos ịpročiai, maisto produktai, gèrimai.

\section{Santrauka}

Tikslas. Ištirti ir įvertinti Lietuvos bendrojo ugdymo mokyklas lankančių mokyklinio amžiaus vaikų mitybos ịpročius.

Tyrimo medžiaga ir metodai. Tyrimas vyko $2018 \mathrm{~m}$. rugsèjo - gruodžio mènesiais. Anketiniu apklausos būdu ištirti ir ịvertinti 4623 bendrojo ugdymo mokyklas lankančių 1-12 klasių vaikų mitybos ịpročiai. Apklausa anoniminé, tiriamųjų vardai ir pavardès nebuvo rašomos, analizuojami tik apibendrinti apklausos duomenys. Statistiné duomenų analizè atlikta naudojant SPSS programos 18.0 versiją. Rezultatu skirtumas laikytas reikšmingu, kai gautoji p reikšmé buvo mažesnè arba lygi 0,05 .

Tyrimo rezultatai parodè, kad mažiau kaip pusè (41 proc.) mokyklinio amžiaus vaikų valgo 4-5 kartus per parą; tik du trečdaliai pusryčiauja kasdien ir kas antras valgo mokykloje karštus pietus. Nustatyta, kad daržovių vartojimo dažnumas yra beveik toks pat, kaip ir vaisių bei uogų - juos kasdien vartoja tik du trečdaliai vaikų. Daugelis (71,3 proc.) kasdien vartoja mėsą ir mėsos produktus, daugiau kaip pusé $(65,8$ proc.) - pieną ir pieno produktus, tačiau beveik tiek pat vaikų (64,9 proc.) žuvị ir žuvies produktus vartoja tik kelis kartus per mėnesi arba jų nevartoja. Kas penktas apklausos dalyvis (19,9 proc.) atsakè, kad kasdien vartoja bulvių, kukurūzų ir kitus traškučius, kitus riebaluose virtus, skrudintus ar spragintus gaminius, kai kurie - saldumynus (39,3 proc.), geria įvairius gazuotus ir (ar) saldžiuosius gėrimus (23,5 proc.). Energinių gèrimų vaikai beveik nevartoja ( 90,5 proc.) arba juos vartoja tik kelis kartus per mènesị.
Jaunesni vaikai, palyginti su vyresniais, berniukai, palyginti su mergaitèmis, dažniau valgo 4 ir daugiau kartų per parą, dažniau pusryčiauja bei valgo karštus pietus mokykloje, dažniau vartoja pieną ir pieno produktus bei mèsą ir jos produktus. Jaunesni vaikai, palyginti su vyresniais, taip pat dažniau valgo daržoves (išskyrus bulves), vaisius ir uogas, žuvị ir jos produktus. Daržoves šiek tiek dažniau valgo mergaitès, negu berniukai, mieste, negu kaime gyvenantys vaikai. Miestų vaikai dažniau pusryčiauja ir vartoja pieną bei jo produktus; kaimų - dažniau valgo karštus pietus mokykloje, vartoja mėsą ir jos produktus. Išvados. Ne visų mokyklinio amžiaus vaikų mitybos ipročiai atitinka sveikos mitybos rekomendacijas. Visi vaikai, nepriklausomai nuo amžiaus, per mažai vartoja sveikatai palankių maisto produktų - daržovių, vaisių, uogų, žuvies ir jos gaminių. Nemažai vaikų, dažniausiai 11-14 metų (5-8 klasès), vis dar vartoja sveikatai nepalankius maisto produktus - bulvių, kukurūzų ir kitus traškučius, kitus riebaluose virtus, skrudintus ar spragintus gaminius, saldumynus, geria ịvairius gazuotus ir (ar) saldžiuosius gerimus.

\section{Ivadas}

Vaikyste ir paauglyste - laikotarpis, kai formuojasi sveikos gyvensenos bei mitybos įpročiai ir išmokstama gyventi sveikai. Būtent šiuo laikotarpiu labai svarbu, kad vaikai ne tik gautų teisingą informaciją apie sveiką mitybą ir jos reikšmę organizmui, bet mokètų tinkamai pasirinkti sveikatai palankius maisto produktus ir formuotųsi sveikos mitybos ipročiai [1-3]. Nors ryšys tarp mitybos ankstyvame amžiuje ir sveikatos vyresniame amžiuje patvirtintas moksliniais ịrodymais, tačiau ir Lietuvos, ir kitų šaliu vaikų gyvensena bei mityba dar nèra gera - vaikai vartoja per mažai daržovių ir vaisių bei uogų, saldžiai užkandžiauja, mėgsta greitai 
pagaminamą maistą, nesilaiko maitinimosi režimo ir pan. [4-12]. Dèl šių priežasčių nacionaliniuose, Pasaulio sveikatos organizacijos bei Europos Sąjungos strateginiuose dokumentuose skatinama tirti bei vertinti mitybą, spręsti su ja susijusias sveikatos problemas, dar aktyviau imtis visų priemonių, skatinančių visuomenę, o ypač vaikus ir jaunimą, sveikai maitintis. Tikslas - mažinti lètinių neinfekcinių ligų ir jų rizikos veiksnių paplitimą bei ieškoti būdų, užtikrinančių didesnę sveikatai palankesnių maisto produktų pasiūlą ir galimybes rinktis tokius maisto produktus [1, 13-15].

Sveikatos mokymo ir ligų prevencijos centras, vykdydamas 2014-2020 m. Europos Sajungos fondų investicijų programos 8 prioriteto „Socialinès įtraukties didinimas ir kova su skurdu“ igyvendinimo priemonès Nr.08.4.2-ESFA-V-622 „Vaikų ligų, traumų ir nelaimingų atsitikimų profilaktika, sveikatos priežiūros paslaugų vaikams prieinamumo ir kokybès gerinimas“ projektą „Vaikams ir paaugliams palankių, kokybiškų ir veiksmingų visuomenès sveikatos priežiūros paslaugų plètojimas“, 2018 m. rugsèjo 2019 m. gruodžio mènesį atliko mokyklinio amžiaus vaikų faktinès mitybos ir fizinio aktyvumo tyrimą ir vertinimą. Straipsnyje pateikiami vaikų mitybos ipročių tyrimo duomenys.

Tyrimo tikslas - ištirti Lietuvos bendrojo ugdymo mokyklas lankančių mokyklinio amžiaus vaikų mitybos ịpročius.

\section{Tyrimo medžiaga ir metodai}

Tyrimo tikslinè grupé - Lietuvos bendrojo ugdymo mokyklas lankantys 1-12 klasių vaikai. Remiantis viešai prieinamais statistiniais duomenimis Švietimo valdymo informacineje sistemoje (http:// www.svis.smm.lt/), sudaryta atsitiktine tyrimo imtis, reprezentuojanti Lietuvos mokyklinio amžiaus vaikus, lankančius bendrojo ugdymo mokyklas (toliau - vaikai), pagal amžių, lytį, gyvenamają vietą (miestas ar kaimas) ir apskriti. Vaikų apklausą atsitiktinės atrankos būdu atrinktose bendrojo ugdymo programas vykdančiose mokyklose atliko UAB „Eurointegracijos projektai““. Mitybos ịpročiu tyrimui buvo naudojama anketa (kappa 0,61 ir >), kurią sudarè klausimai apie bendruosius duomenis (gyvenamoji vieta, lytis, klasè, kurioje vaikas mokosi) ir apie maitinimosi ịpročius (valgymo dažnumas, kai kurių maisto produktų ir gerimų vartojimo dažnumas ir pan.). Apklausa (anketa) anoniminè, vaiku vardai ir pavardès nebuvo rašomi, visi apklausos duomenys analizuojami tik apibendrinti. Anketiniu apklausos būdu iš viso buvo ištirti ir įvertinti 4623 respondentų mitybos ịpročiai.

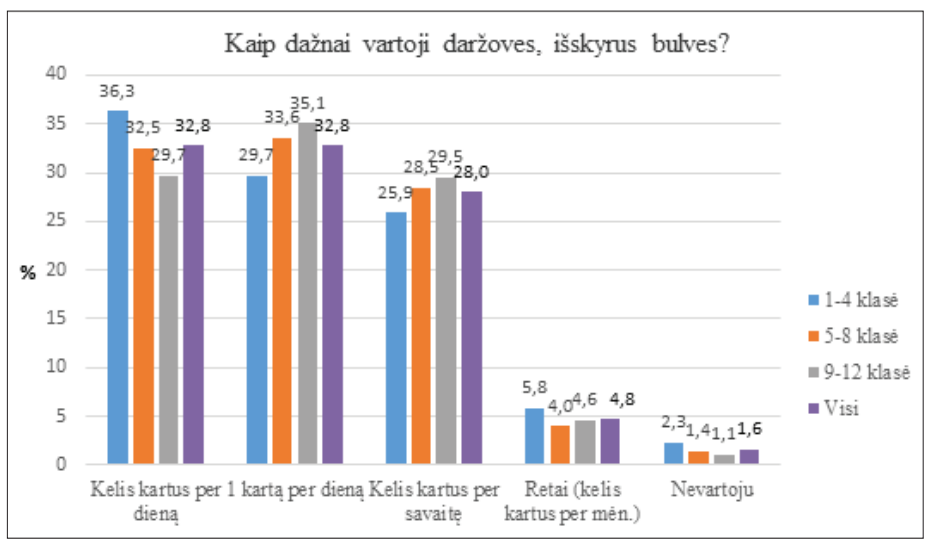

1 pav. Daržovių (išskyrus bulves) vartojimo dažnis (proc.), priklausomai nuo mokymosi klasès $(p<0,001)$.

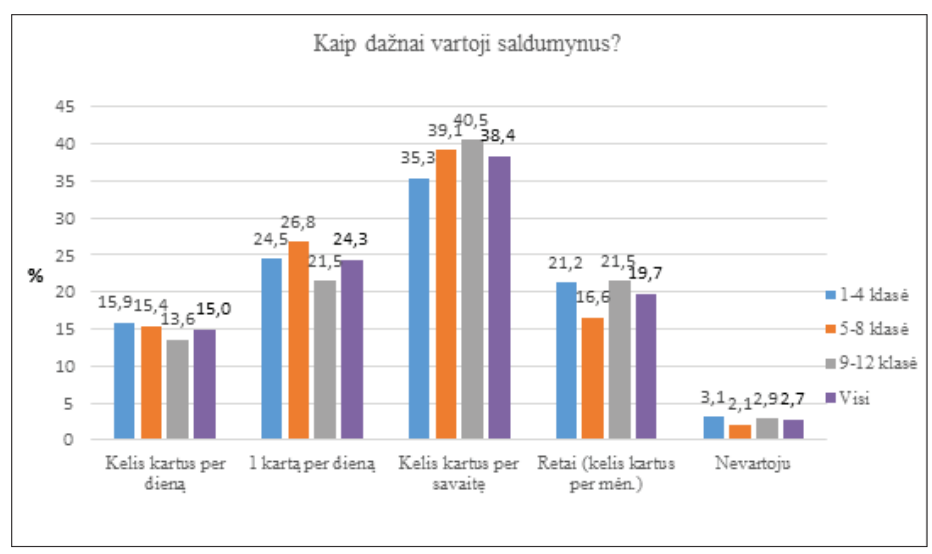

2 pav. Saldumynų (šokolado, saldainių, pyragaičių, tortų ir kt.) vartojimo dažnis, priklausomai nuo mokymosi klasès $(\mathrm{p}<0,001)$.

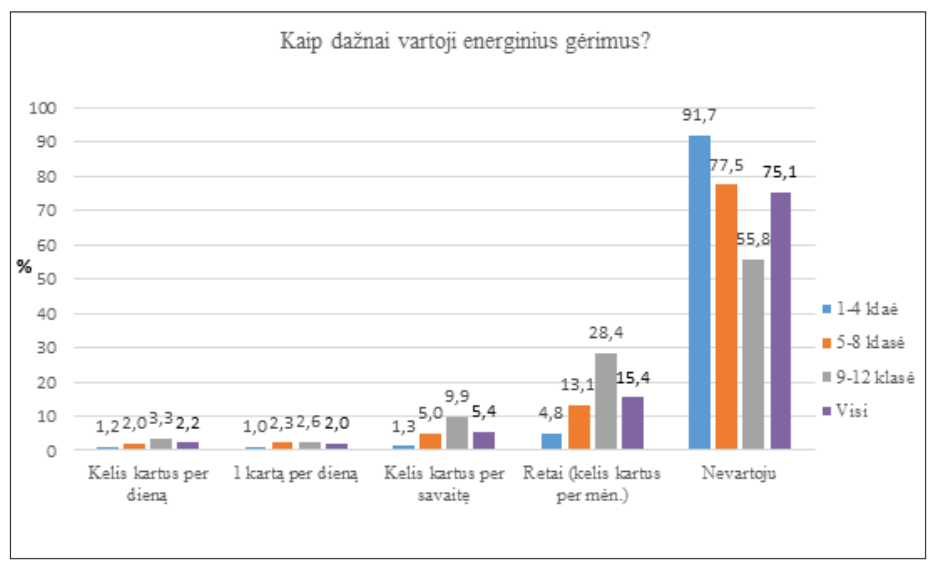

3 pav. Energinių gėrimų vartojimo dažnis (proc.), priklausomai nuo mokymosi klasès $(\mathrm{p}<0,001)$. 
Statistinè duomenų analizė atlikta naudojant SPSS programos 18.0 versiją. Kategorinių duomenų analizei naudotas $\chi^{2}$ (chi kvadrato) kriterijus ir Fisher tikslusis metodas. Rezultatų skirtumas laikytas reikšmingu, kai gautoji p reikšmė buvo mažesnè arba lygi 0,05.

\section{Rezultatai}

Mitybos ịpročiu tyrime dalyvavo 4623 mokyklinio amžiaus vaikai, iš kurių 2274 (49,2 proc.) buvo berniukai ir 2349 (50,8 proc.) - mergaitès. Dauguma ( 70,1 proc.) tyrime

1 lentelè. Maisto produktų vartojimo dažnis (proc.), priklausomai nuo lyties, klasės ir gyvenamosios vietos.

\begin{tabular}{|c|c|c|c|c|c|}
\hline $\begin{array}{l}\text { R e s p o n - } \\
\text { dentų grupės } \\
\text { pagal }\end{array}$ & $\begin{array}{c}\text { Kelis } \\
\text { kartus } \\
\text { per } \\
\text { dieną }\end{array}$ & $\begin{array}{c}1 \text { kartą } \\
\text { per } \\
\text { dieną }\end{array}$ & $\begin{array}{c}\text { Kelis } \\
\text { kartus } \\
\text { per } \\
\text { savaitę }\end{array}$ & $\begin{array}{l}\text { Retai (ke- } \\
\text { lis kartus } \\
\text { per mèn.) }\end{array}$ & $\begin{array}{c}\text { Nevar- } \\
\text { toja }\end{array}$ \\
\hline \multicolumn{6}{|c|}{ Daržovès (išskyrus bulves) } \\
\hline \multicolumn{6}{|c|}{ Lyti $\left(\chi^{2}=13,508, \mathrm{df}=4, \mathrm{p}<0,009\right)$} \\
\hline Berniukas & 31,0 & 34,0 & 28,1 & 4,8 & 2,1 \\
\hline Mergaite & 34,6 & 31,6 & 27,9 & 4,8 & 1,1 \\
\hline \multicolumn{6}{|c|}{ Klasę $\left(\chi^{2}=34,587, \mathrm{df}=8, \mathrm{p}<0,001\right)$} \\
\hline 1-4 klasė & 36,3 & 29,7 & 25,9 & 5,8 & 2,3 \\
\hline 5-8 klasè & 32,5 & 33,6 & 28,5 & 4,0 & 1,4 \\
\hline 9-12 klasė & 29,7 & 35,1 & 29,5 & 4,6 & 1,1 \\
\hline \multicolumn{6}{|c|}{ Gyvenamają vietą $\left(\chi^{2}=13,838, \mathrm{df}=4, \mathrm{p}<0,008\right)$} \\
\hline Miestas & 33,4 & 33,1 & 27,4 & 4,3 & 1,9 \\
\hline Kaimas & 31,5 & 32,1 & 29,4 & 6,0 & 0,9 \\
\hline Iš viso: & 32,8 & 32,8 & 28,0 & 4,8 & 1,6 \\
\hline \multicolumn{6}{|l|}{ Vaisiai, uogos } \\
\hline \multicolumn{6}{|c|}{ Lyti $\left(\chi^{2}=8,232, d f=4, p>0,083\right)$} \\
\hline Berniukas & 37,7 & 27,0 & 28,5 & 5,9 & 0,9 \\
\hline Mergaitè & 40,6 & 26,4 & 27,8 & 4,5 & 0,7 \\
\hline \multicolumn{6}{|c|}{ Klasę $\left(\chi^{2}=111,335, \mathrm{df}=8, \mathrm{p}<0,001\right)$} \\
\hline 1-4 klasè & 47,4 & 27,3 & 24,2 & 5,2 & 0,9 \\
\hline $5-8$ klasė & 40,6 & 27,5 & 26,9 & 4,5 & 0,6 \\
\hline 9-12 klasė & 29,4 & 30,4 & 33,4 & 5,9 & 0,9 \\
\hline \multicolumn{6}{|c|}{ Gyvenamają vietą $\left(\chi^{2}=0,545, \mathrm{df}=4, \mathrm{p}>0,969\right)$} \\
\hline Miestas & 38,9 & 26,7 & 28,3 & 5,2 & 0,8 \\
\hline Kaimas & 39,8 & 26,8 & 27,6 & 5,1 & 0,7 \\
\hline Iš viso: & 39,2 & 26,7 & 28,1 & 5,2 & 0,8 \\
\hline \multicolumn{6}{|c|}{ Pienas ir pieno produktai } \\
\hline \multicolumn{6}{|c|}{ Lyti $\left(\chi^{2}=28,055, \mathrm{df}=4, \mathrm{p}<0,001\right)$} \\
\hline Berniukas & 39,1 & 29,6 & 23,0 & 6,5 & 1,2 \\
\hline Mergaitè & 32,3 & 30,7 & 28,3 & 6,7 & 2,0 \\
\hline \multicolumn{6}{|c|}{ Klasę $\left(\chi^{2}=35,332, \mathrm{df}=8, \mathrm{p}<0,001\right)$} \\
\hline 1-4 klasė & 37,4 & 29,3 & 25,1 & 7,0 & 1,2 \\
\hline 5-8 klasė & 38,4 & 30,4 & 22,8 & 6,4 & 2,0 \\
\hline
\end{tabular}

dalyvavusių vaikų gyveno mieste, kiti (29,9 proc.) - kaime. Respondentai pagal amžiaus grupes pasiskirstė beveik vienodai: 7-10 m. arba 1-4 kl. vaikų buvo 1503 (32,5 proc.), 11-14 m. arba 5-8 kl. vaikų buvo 1620 (35,0 proc.) ir 15-18 (19) m. arba 9-12 kl. vaikų buvo 1500 (32,4 proc.).

Išanalizavus vaikų mitybos ịpročiu tyrimo duomenis, nustatyta, kad mokyklinio amžiaus vaikai ne visada laikosi maitinimosi režimo. Taip, kaip rekomenduojama, 4-5 kartus per dieną ir dažniau valgo mažiau kaip pusè (41 proc.) visų tirtų vaikų; didžioji dalis (76,7 proc.) vaikų atsakè, kad valgo 3-4 kartus per dieną; penkis kartus ir dažniau per dieną maitinasi tik kas dešimtas vaikas (10,3 proc.), o maždaug kas devintas (11,4 proc.) valgo tik 2 kartus per dieną; pavieniais atvejais vaikai (1,7 proc.) nurodé, kad maitinasi tik vieną kartą per dieną. Nustatyta, kad 4 kartus per dieną ir daugiau valgo statistiškai reikšmingai $(p>0,001)$ daugiau jaunesnių vaikų

\begin{tabular}{|c|c|c|c|c|c|}
\hline 9-12 klasè & 30,9 & 30,8 & 29,3 & 6,5 & 2,5 \\
\hline \multicolumn{6}{|c|}{ Gyvenamają vietą $\left(\chi^{2}=26,776, \mathrm{df}=4, \mathrm{p}<0,001\right)$} \\
\hline Miestas & 33,6 & 31,5 & 23,9 & 6,2 & 1,8 \\
\hline Kaimas & 33,3 & 27,1 & 29,8 & 7,6 & 2,2 \\
\hline Iš viso: & 35,6 & 30,2 & 25,7 & 6,6 & 1,9 \\
\hline \multicolumn{6}{|c|}{ Mėsa ir jos produktai (vištiena, jautiena ir kt.) } \\
\hline \multicolumn{6}{|c|}{ Lyti $\left(\chi^{2}=60,727, \mathrm{df}=4, \mathrm{p}<0,001\right)$} \\
\hline Berniukas & 39,6 & 35,7 & 20,2 & 3,2 & 1,3 \\
\hline Mergaitè & 29,6 & 37,8 & 26,7 & 3,9 & 2,0 \\
\hline \multicolumn{6}{|c|}{ Klasę $\left(\chi^{2}=26,354, \mathrm{df}=8, \mathrm{p}<0,001\right)$} \\
\hline 1-4 klasè & 32,6 & 35,4 & 25,0 & 5,2 & 1,9 \\
\hline 5-8 klasė & 35,1 & 38,3 & 22,5 & 2,9 & 1,2 \\
\hline 9-12 klasė & 35,8 & 36,5 & 23,2 & 2,6 & 1,9 \\
\hline \multicolumn{6}{|c|}{ Gyvenamają vietą $\left(\chi^{2}=20,974, \mathrm{df}=4, \mathrm{p}<0,001\right)$} \\
\hline Miestas & 32,5 & 37,8 & 24,1 & 3,8 & 1,8 \\
\hline Kaimas & 39,3 & 34,2 & 22,1 & 3,0 & 1,3 \\
\hline Iš viso: & 34,5 & 36,8 & 23,5 & 3,5 & 1,7 \\
\hline \multicolumn{6}{|c|}{\begin{tabular}{|l} 
Žuvis ir žuvies produktai \\
\end{tabular}} \\
\hline \multicolumn{6}{|c|}{ Lytị $\left(\chi^{2}=23,241, \mathrm{df}=5, \mathrm{p}<0,001\right)$} \\
\hline Berniukas & 3,5 & 6,4 & 27,6 & 41,6 & 20,8 \\
\hline Mergaitè & 2,1 & 4,4 & 26,1 & 45,2 & 22,2 \\
\hline \multicolumn{6}{|c|}{ Klasę $\left(\chi^{2}=93,039, \mathrm{df}=10, \mathrm{p}<0,001\right)$} \\
\hline 1-4 klasė & 4,4 & 7,1 & 22,8 & 41,3 & 24,6 \\
\hline 5-8 klasė & 2,4 & 5,1 & 26,2 & 42,6 & 23,6 \\
\hline 9-12 klasè & 1,6 & 4,1 & 31,6 & 46,5 & 16,3 \\
\hline \multicolumn{6}{|c|}{ Gyvenamają vietą $\left(\chi^{2}=31,671, \mathrm{df}=5, \mathrm{p}<0,001\right)$} \\
\hline Miestas & 2,4 & 4,6 & 25,9 & 44,7 & 22,4 \\
\hline Kaimas & 3,7 & 7,4 & 29,0 & 40,4 & 19,5 \\
\hline Iš viso: & 2,8 & 5,4 & 26,8 & 43,4 & 21,5 \\
\hline
\end{tabular}


(1-4 kl.), lyginant su vyresniais, ir statistiškai reikšmingai ( $>00,001)$ daugiau berniukų, negu mergaičių.

Tik 62,1 proc. vaikų valgo pusryčius kiekvieną dieną ir tik maždaug kas antras (51,2 proc.) valgo mokykloje karštus pietus. Nustatyta, kad statistiškai reikšmingai $(\mathrm{p}<0,001)$ daugiau jaunesnių, negu vyresnių vaikų pusryčiauja kasdien ir valgo karštus pietus mokykloje. Statistiškai reikšmingai $(p<0,001)$ daugiau pusryčius kiekvieną dieną ir karštus pietus mokykloje valgo berniukų, negu mergaičių, tačiau kasdien pusryčius valgo daugiau miesto, o karštus pietus mokykloje - kaimo vaikų. Kasdien pusryčių nevalgantys vaikai nurodè pagrindinę nevalgymo priežastį: ,„nenoriu (nemėgstu) valgyti pusryčiu“", ,,valgyčiau, bet nespejju“, o nevalgantys karštų pietų mokykloje atsake ,pietauju namie“

2 lentelè. Sveikatai nepalankių maisto produktų vartojimo dažnis (proc.), priklausomai nuo lyties, klasės ir gyvenamosios vietos.

\begin{tabular}{|c|c|c|c|c|c|}
\hline $\begin{array}{l}\text { Respon- } \\
\text { dentų } \\
\text { grupès } \\
\text { pagal }\end{array}$ & $\begin{array}{c}\text { Kelis } \\
\text { kartus } \\
\text { per } \\
\text { dieną }\end{array}$ & $\begin{array}{c}1 \\
\text { kartą } \\
\text { per } \\
\text { dieną }\end{array}$ & $\begin{array}{c}\text { Kelis } \\
\text { kartus } \\
\text { per } \\
\text { savaitę }\end{array}$ & $\begin{array}{l}\text { Retai (ke- } \\
\text { lis kartus } \\
\text { per mèn.) }\end{array}$ & $\begin{array}{c}\text { Nevar- } \\
\text { toja }\end{array}$ \\
\hline \multicolumn{6}{|c|}{$\begin{array}{l}\text { Bulvių, kukurūzų ir kiti traškučiai, kiti riebaluose virti, } \\
\text { skrudinti ar spraginti gaminiai }\end{array}$} \\
\hline \multicolumn{6}{|c|}{ Lyti $\left(\chi^{2}=72,518, \mathrm{df}=4, \mathrm{p}<0,001\right)$} \\
\hline Berniukas & 9,7 & 14,5 & 37,8 & 33,2 & 4,8 \\
\hline Mergaitè & 5,7 & 10,0 & 36,1 & 43,0 & 5,1 \\
\hline \multicolumn{6}{|c|}{ Klasę $\left(\chi^{2}=81,064, \mathrm{df}=8, \mathrm{p}<0,001\right)$} \\
\hline 1-4 klasė & 8,1 & 12,7 & 33,2 & 40,2 & 5,8 \\
\hline 5-8 klasė & 9,1 & 15,1 & 39,1 & 33,6 & 3,0 \\
\hline 9-12 klasė & 5,7 & 8,6 & 38,3 & 41,2 & 6,1 \\
\hline \multicolumn{6}{|c|}{ Gyvenamąą vietą $\left(\chi^{2}=45,207, \mathrm{df}=4, \mathrm{p}<0,001\right)$} \\
\hline Miestas & 7,0 & 10,5 & 37,8 & 39,9 & 5,5 \\
\hline Kaimas & 9,3 & 16,4 & 35,0 & 35,7 & 3,7 \\
\hline Iš viso: & 7,7 & 12,2 & 36,9 & 36,9 & 4,9 \\
\hline \multicolumn{6}{|c|}{$\begin{array}{l}\text { Saldumynai } \\
\text { (saldainiai, šokoladas, vafliai su pertepu, pyragaičiai su kremu } \\
\text { ar glaistu, tortai ir kt.) }\end{array}$} \\
\hline \multicolumn{6}{|c|}{ Lyti $\left(\chi^{2}=19,073, \mathrm{df}=4, \mathrm{p}<0,001\right)$} \\
\hline Berniukas & 14,2 & 24,0 & 37,6 & 20,5 & 3,6 \\
\hline Mergaitè & 15,7 & 24,7 & 39,0 & 18,9 & 1,7 \\
\hline \multicolumn{6}{|c|}{ Klasę $\left(\chi^{2}=32,592, \mathrm{df}=8, \mathrm{p}<0,001\right)$} \\
\hline 1-4 klasè & 15,9 & 24,5 & 35,3 & 21,2 & 3,1 \\
\hline 5-8 klasė & 15,4 & 26,8 & 39,1 & 16,6 & 2,1 \\
\hline 9-12 klasè & 13,6 & 21,5 & 40,5 & 21,5 & 2,9 \\
\hline \multicolumn{6}{|c|}{ Gyvenamąją vietą $\left(\chi^{2}=8,390, \mathrm{df}=4, \mathrm{p}>0,078\right)$} \\
\hline Miestas & 14,4 & 24,6 & 39,4 & 19,0 & 2,6 \\
\hline
\end{tabular}

(beveik kas antras nevalgantis karštų pietų mokykloje vaikas) ir „,neskanus arba atvėsęs maistas“ (daugiau kaip kas trečias jo nevalgantis).

Išanalizavus mokyklinio amžiaus vaikų atsakymus ị klausimą „Kaip dažnai vartoji daržoves (šviežius, virtus, keptus, troškintus, raugintus ir pan. agurkus, pomidorus, morkas, burokèlius, brokolius, salotas ir kt.), išskyrus bulves?" nustatyta, kad tik daugiau kaip pusè (65,6 proc.) vaikų kasdien valgo daržoves, iš kurių trečdalis jas valgo vieną kartą per dieną ir trečdalis - kelis kartus per dieną; taip pat beveik trečdalis vaikų valgo daržoves tik kelis kartus per savaitę, o kiti $(6,4$ proc.) daržovių nevalgo arba labai retai - tik kelis kartus per mènesị (1 lentelè). Statistiškai reikšmingai daugiau vyresnių, negu jaunesnių vaikų daržoves (išskyrus bulves) vartoja retai - kelis kartus per savaitę (1 pav.). Šiek tiek dažniau daržoves (išskyrus bulves) vartoja mergaitès, palyginus su berniukais ir statistiškai reikšmingai $(\mathrm{p}<0,008)$ dažniau miesto, negu kaimo vaikai.

\begin{tabular}{|l|l|l|l|l|l|}
\hline Kaimas & 16,2 & 23,7 & 35,9 & 21,3 & 2,8 \\
\hline Iš viso: & 15,0 & 24,3 & 38,4 & 19,7 & 2,7 \\
\hline
\end{tabular}

\section{Ivairūs gazuoti ir (ar) saldieji gèrimai}

Lyti $\left(\chi^{2}=115,080, \mathrm{df}=4, \mathrm{p}<0,001\right)$

\begin{tabular}{|l|c|c|c|c|c|}
\hline Berniukas & 13,3 & 16,1 & 35,5 & 28,5 & 6,6 \\
\hline Mergaite் & 7,5 & 10,5 & 33,5 & 39,2 & 9,3 \\
\hline Klasę $\left(\chi^{2}=103,729, \mathrm{df}=8, \mathrm{p}<0,001\right)$ \\
\hline 1-4 klasé & 9,3 & 12,9 & 28,5 & 39,7 & 9,5 \\
\hline 5-8 klase & 12,0 & 16,2 & 38,5 & 27,8 & 5,5 \\
\hline 9-12 klase் & 9,6 & 10,3 & 36,1 & 34,7 & 9,2
\end{tabular}

Gyvenamają vietą $\left(\chi^{2}=44,267, \mathrm{df}=4, \mathrm{p}<0,001\right)$

\begin{tabular}{|l|c|c|c|c|c|}
\hline Miestas & 9,2 & 12,0 & 34,2 & 35,9 & 8,6 \\
\hline Kaimas & 13,0 & 16,2 & 35,0 & 29,3 & 6,5 \\
\hline Iš viso: & 10,3 & 13,2 & 34,5 & 33,9 & 8,0 \\
\hline
\end{tabular}

\section{Energiniai gèrimai}

Lyti $\left(\chi^{2}=85,301, \mathrm{df}=4, \mathrm{p}<0,001\right)$

\begin{tabular}{|l|l|l|l|l|l|}
\hline Berniukas & 3,6 & 2,3 & 6,7 & 17,2 & 70,1 \\
\hline Mergaite & 0,8 & 1,7 & 4,1 & 13,6 & 79,9 \\
\hline
\end{tabular}

Klasę $\left(\chi^{2}=541,046, \mathrm{df}=8, \mathrm{p}<0,001\right)$

\begin{tabular}{|l|c|c|c|c|c|}
\hline 1-4 klasé & 1,2 & 1,0 & 1,3 & 4,8 & 91,7 \\
\hline 5-8 klasé & 2,0 & 2,3 & 5,0 & 13,1 & 77,5 \\
\hline 9-12 klasė & 3,3 & 2,6 & 9,9 & 28,4 & 55,8 \\
\hline
\end{tabular}

Gyvenamają vietą $\left(\chi^{2}=51,850, \mathrm{df}=4, \mathrm{p}<0,001\right)$

\begin{tabular}{|l|l|l|l|l|l|}
\hline Miestas & 1,7 & 1,6 & 4,6 & 14,2 & 77,9 \\
\hline Kaimas & 3,3 & 2,9 & 7,2 & 18,1 & 68,5 \\
\hline Iš viso: & 2,2 & 2,0 & 5,4 & 15,4 & 75,1 \\
\hline
\end{tabular}


Nustatyta, kad vaikų vaisių ir uogų vartojimo dažnumas yra beveik toks pat, kaip ir daržovių (1 lentelè). Kelis kartus per dieną vaisius ir uogas vartoja šiek tiek didesnè dalis vaikų, negu daržoves. Kai kurie (6,0 proc.) atsakè, kad vaisius ir uogas valgo arba labai retai, tik kelis kartus per mènesi ( 5,2 proc.), arba jų visai nevalgo ( 0,8 proc.). Vyresni vaikai, palyginus su jaunesniais, vaisius ir uogas, kaip ir daržoves, vartoja rečiau; statistiškai reikšmingų skirtumų pagal respondentų vaisių ir uogų vartojimo dažnumą priklausomai nuo lyties ir gyvenamosios vietos nenustatyta.

Tyrimo duomenys parode, kad beveik du trečdaliai $(65,8$ proc.) vaikų pieną ir pieno produktus vartoja kasdien (vieną ir kelis kartus per dieną), kas ketvirtas $(25,7$ proc.) - kelis kartus per savaitę, kiti (6,6 proc.) - labai retai (kelis kartus per mènesį). Tik kai kurie vaikai (1,9 proc.) atsake, kad šių produktų nevartoja. Pieną ir pieno produktus statistiškai reikšmingai $(p<0,001)$ dažniau vartoja jaunesni $(1-4$ ir 5-8 kl.), negu vyresni (9-12 kl.) vaikai, berniukai, negu mergaitès ir mieste, negu kaime, gyvenantys vaikai.

Dauguma (71,3 proc.) tyrimo dalyvių mèsą ir mésos produktus (vištieną, jautieną, kiaulieną ir kt.) vartoja kasdien (vieną ir kelis kartus per dieną), beveik kas ketvirtas (23,5 proc.) - kelis kartus per savaitę, kiti (5,2 proc.) juos valgo labai retai (kelis kartus per mėnesị) arba nevalgo. Šiek tiek didesnè dalis vyresnių (5-12 kl.), negu jaunesnių (1-4 kl.) vaikų mèsą ir mėsos produktus vartoja kasdien vieną arba kelis kartus per dieną. Didesnè dalis jaunesnių, negu vyresnių vaikų mėsą ir mėsos produktus vartoja tik kelis kartus per savaitę, arba retai (kelis kartus per mėnesį). Mèsą ir jos produktus kasdien vartoja statistiškai reikšmingai $(\mathrm{p}<0,001)$ daugiau berniukų, negu mergaičių ir kaime, negu mieste, gyvenančių vaikų. Tik maždaug trečdalis vaikų atsakè, kad žuvị ir jos produktus vartoja kelis kartus per savaitę ir kiekvieną dieną, o didžioji dalis (64,9 proc.) vaikų, skirtingai negu pieno ir mésos produktus, žuvị ir žuvies produktus vartoja labai retai (tik kelis kartus per ménesį) arba jų visai nevartoja (1 lentelè). Kelis kartus per savaitę ir kasdien vartojančių žuvị ir žuvies produktus daugiau yra vyresnių (9-12 kl.), negu jaunesniu (1-4 ir 5-8 kl.) vaiku ir daugiau berniuku bei kaime gyvenančių vaikų (1 lentelè).

Vaikų buvo klausiama, kaip dažnai jie vartoja sveikatai nepalankius maisto produktus. Išanalizavus respondentų atsakymus ị klausimą „Kaip dažnai vartoji bulvių, kukurūzų ir kitus traškučius, kitus riebaluose virtus, skrudintus ar spragintus gaminius (gruzdintas bulvytes, spurgas, žagarèlius, čeburekus ir pan.)?" nustatyta, kad net kas penktas (19,9 proc.) vaikas kasdien (vieną ir kelis kartus per dieną) vartoja šiuos sveikatai nepalankius maisto produktus, 36,9 proc. vaiku juos vartoja kelis kartus per savaitę ir tik 41,8 proc. - labai retai (kelis kartus per mėnesî) arba nevartoja (2 lentelè). Nustatyti statistiškai reikšmingi $(\mathrm{p}<0,001)$ skirtumai pagal bulvių, kukurūzų ir kitų traškučių, kitų riebaluose virtų, skrudintų ar spragintų gaminių vartojimo dažnumą, priklausomai nuo amžiaus (klasès, kurioje mokosi): kasdien (vieną ir kelis kartus per dieną) šiuos produktus vartoja kas penktas (20,8 proc.) 1-4 kl. mokinys, kas ketvirtas (24,2 proc.) 5-8 kl. ir kas septintas (14,3 proc.) 9-12 kl. mokinys. Stebima tendencija, kad jaunesni (1-4 kl.) vaikai, palyginus su vyresniais (9-12 kl.), dažniau vartoja šiuos produktus, tačiau dažniausiai $-5-8$ klasių mokiniai. Taip pat statistiškai reikšmingai $(p<0,001)$ daugiau berniukų, negu mergaičių ir dažniau kaime, negu mieste gyvenančių vaikų vartoja bulvių, kukurūzų ir kitus traškučius, kitus riebaluose virtus, skrudintus ar spragintus gaminius kasdien nuo vieno iki kelių kartų per dieną, arba kelis kartus per savaitę.

Atlikto tyrimo duomenimis, saldumynus (saldainius, šokoladą, vaflius su pertepu, pyragaičius su kremu ar glaistu, tortus ir kt.) kasdien (vieną ir kelis kartus per dieną) vartoja 39,3 proc. mokyklinio amžiaus vaikų, iš kurių kas ketvirtas ( 24,3 proc.) saldumynus valgo vieną kartą per dieną ir beveik kas septintas (15,0 proc.) - kelis kartus per dieną; panaši dalis vaikų, kaip ir kiekvieną dieną vartojančių saldumynus (39,3 proc.), juos vartoja kelis kartus per savaitę (38,4 proc.); tik labai maža dalis ( 2,7 proc.) vaikų atsakè, kad saldumynų nevalgo. Nustatyta, kad vyresni vaikai, palyginus su jaunesniais, rečiau vartoja saldumynus, tačiau, kaip ir bulvių, kukurūzų ir kitus traškučius, kitus riebaluose virtus, skrudintus ar spragintus gaminius, taip ir saldumynus, dažniausiai vartoja 5-8 kl. (11-14 m.) vaikai (2 pav.).

Saldumynus dažniau vartoja mergaitès, negu berniukai, o statistiškai reikšmingų saldumynų vartojimo dažnumo skirtumų, priklausomai nuo mokinių gyvenamosios vietos, nenustatyta.

Nepriklausomai nuo vaikų amžiaus, lyties bei gyvenamosios vietos, kas ketvirtas (23,5 proc.) mokyklinio amžiaus vaikas atsakè, kad kasdien (vieną ir kelis kartus per dieną) geria ịvairius gazuotus ir (ar) saldžiuosius gérimus, tokius kaip Pepsi, Coca cola, Fanta, Sprite ir pan.; 41,9 proc. vaiku juos vartoja retai ir labai retai (kelis kartus per mènesi) arba nevartoja (atitinkamai 33,9 proc. ir 8,0 proc.), o beveik kas trečias (34,5 proc.) atsaké, kad įvairius gazuotus ir (ar) saldžiuosius gèrimus vartoja kelis kartus per savaitę (1 lentelè). Statistiškai reikšmingai $(\mathrm{p}<0,001)$ daugiausia atsakiusių, kad ivvairius gazuotus ir (ar) saldžiuosius gérimus vartoja retai (kelis kartus per mènesį), arba iš viso jų nevartoja, buvo jauniausio amžiaus (1-4 kl.), o mažiausiai - 5-8 kl. mokinių grupeje (33,3 proc.); kad kasdien (vieną ir kelis kartus per dieną) vartoja gazuotus ir (ar) saldžiuosius gérimus atsakè beveik kas penktas 1-4 kl. ir 9-12 kl. ir beveik kas trečias 5-8 klasių mokinys. Dažniausiai sveikatai nepalankius įvai- 
rius gazuotus ir (ar) saldžiuosius gèrimus vartoja 5-8 kl. mokiniai (11-14 m. amžiaus paaugliai). Juos statistiškai reikšmingai $(p<0,001)$ dažniau vartoja berniukai, negu mergaitès, ir kaime, negu mieste gyvenantys vaikai.

Nustatyta, kad energinių gèrimų arba nevartoja, arba juos vartoja tik kelis kartus per ménesį (retai) 90,5 proc. vaikų; nedidelè dalis $(5,4$ proc.) atsakè, kad energinius gèrimus vartoja kelis kartus per savaitę, nors taip pat nedaug, tačiau buvo tokių (4,2 proc. visų vaikų), kurie atsakè, kad energinius gérimus vartoja kasdien, iš jų 2,2 proc. - kelis kartus per dieną ir 2,0 proc. - vieną kartą per dieną ( 2 lentelè). Kuo vyresni vaikai, tuo dažniau jie vartoja energinius gèrimus. Energinių gèrimų nevartoja 91,7 proc. jaunesnių (1-4 kl.), 77,5 proc. 5-8 klasių ir tik 55 proc. vyresnių (9-12 kl.) klasių mokinių ( 3 pav.). Statistiškai reikšmingai $(p<0,001)$ dažniau berniukai, negu mergaitès, ir kaime, negu mieste gyvenantys vaikai atsakè, kad vartoja energinius gèrimus (2 lentelè).

\section{Rezultatų aptarimas}

Apibendrinus vaikų mitybos ịpročių tyrimo duomenis, išryškejjo, kad ne visų mokyklinio amžiaus vaikų mitybos ipročiai atitinka sveikos mitybos rekomendacijas, nemažai vaikų nesilaiko tinkamo maitinimosi režimo ir pan. Vaikams, ypač jaunesniojo mokyklinio amžiaus, rekomenduojama valgyti 4-5 kartus per parą ir dažniau, tačiau nustatyta, kad taip valgo tik 41 proc. visų vaikų. Kiti autoriai taip pat nurodo, kad tik apie trečdalis pradinių klasių mokinių valgo 3 ir tiek pat -4 kartus per dieną, o maitinimosi rekomendacijų laikosi ir penkis kartus per dieną valgo tik dešimtadalis vaikų [5]. Žinoma, kad visi vaikai pusryčius turètų valgyti kasdien, tačiau taip valgo tik du trečdaliai vaikų. Kuo vyresni vaikai, tuo mažesnè jų dalis pusryčiauja kasdien. Kiti autoriai $[4,5$, $7,17,18]$ taip pat nurodo, kad dar nepakankama dalis vaikų pusryčiauja kasdien.

Nustatyta, kad ne tik per maža dalis vaikų valgo pusryčius kasdien, bet ir tik maždaug kas antras vaikas mokykloje valgo karštus pietus, o nevalgymo pagrindinès priežastys „nenoriu (nemėgstu) valgyti pusryčių“, ,valgyčiau, bet nespejju“, ,pietauju namie“, „,neskanus arba atvėsęs maistas“ ir pan.

Moksliniais tyrimais įrodyta, kad sveikatai palankios mitybos ịpročiai susiformuoja vaikysteje. Daug vaisių bei daržovių vaikystejje valgę asmenys ir toliau jų vartoja pakankamai, o tie, kurie jų valgè nedaug, savo ịpročių dažniausiai nekeičia ir vyresniame amžiuje. Sveikos mitybos rekomendacijose daržoves ir vaisius patariama valgyti kasdien ir bent penkis kartus per parą, o Vaisių ir daržovių bei pieno ir pieno produktų vartojimo skatinimo vaikų ugdymo istaigose programos 2017-2023 mokslo metų strategijos, patvirtintos Lietuvos Respublikos žemès ūkio ministro 2017 m. liepos $25 \mathrm{~d}$. ịsakymu Nr. 3D-489, igyvendinimo vertinimo kriterijuose numatyta siekti, kad 70 proc. vaikų, lankančių vaikų ugdymo įstaigas, vaisius ir daržoves vartotų kasdien kelis kartus per dieną. $2019 \mathrm{~m}$. atlikto tyrimo duomenimis, daržovių vartojimo dažnumas yra beveik toks pat, kaip vaisių ir uogų. Tik du trečdaliai vaikų kasdien (vieną ir kelis kartus per dieną) vartoja daržoves ir tiek pat - vaisius bei uogas. Ir nors vaisių ir uogų rekomenduojama vartoti rečiau, negu daržovių, tačiau kelis kartus per parą vaisius ir uogas vartoja šiek tiek didesnè dalis vaikų, palyginus su vartojančiaisiais kelis kartus per dieną daržoves. Nepakankamo vaikų daržovių, vaisių ir uogų vartojimo problemas akcentuoja ir kitų Lietuvos ir užsienio šalių straipsnių autoriai $[4,5,7,17,18]$. Pvz., $2019 \mathrm{~m}$. Suomijoje atlikto tyrimo duomenimis, tik 32,4 proc. vaikų nurodè, kad beveik kasdien vartoja apdorotas daržoves, dažniausiai bulves, 40,1 proc. - bent kartą per dieną vartoja šviežias daržoves ir 32,7 proc. - bent kartą per dieną vartoja vaisius ir uogas [12].

Pastaruoju metu viešojoje erdvejje galima rasti skirtingų nuomonių dèl būtinumo vartoti gyvūninès kilmès maisto produktus, tačiau atlikto tyrimo duomenys parodè, kad didžioji dalis (71,3 proc.) vaikų mèsą ir mèsos produktus vartoja kasdien (vieną ir kelis kartus per dieną) ir tik labai nedidelè dalis vaikų juos valgo labai retai (kelis kartus per mėnesį) arba šių produktų nevartoja. Pieną ir pieno produktus kasdien (vieną ir kelis kartus per dieną) taip pat vartoja maždaug du trečdaliai vaikų, iš jų kas trečias juos vartoja kelis kartus per dieną, nors Vaisių ir daržovių bei pieno ir pieno produktų vartojimo skatinimo strategijos ịgyvendinimo vertinimo kriterijuose numatyta, kad 85 proc. vaikų, lankančių vaikų ugdymo įstaigas, pieną ir pieno gaminius vartotų kasdien kelis kartus per dieną.

Sveikos mitybos rekomendacijose žuvị ir jos produktus rekomenduojama vartoti bent 2-3 kartus per savaitę, tačiau atlikto tyrimo duomenimis, beveik du trečdaliai vaikų žuvị ir žuvies produktus vartoja labai retai (tik kelis kartus per mėnesį), arba jų nevartoja. Tik kas trečias vaikas žuvị ir jos produktus vartoja kelis kartus per savaitę arba kasdien.

Vaikų ugdymo įstaigose draudžiama vaikų maitinimui tiekti sveikatai nepalankius produktus, tokius, kaip bulvių, kukurūzų ar kitokie traškučiai, kiti riebaluose virti, skrudinti ar spraginti gaminiai; saldainiai; šokoladas ir šokolado gaminiai; valgomieji ledai; gazuoti ir energiniai gèrimai ir pan. [16], tačiau net kas penktas vaikas pasaké, kad kasdien (vieną ir kelis kartus per dieną) vartoja sveikatai nepalankius maisto produktus - bulvių, kukurūzų ir kitus traškučius, kitus riebaluose virtus, skrudintus ar spragintus gaminius. Juos vartoja labai retai (kelis kartus per mènesį) arba iš viso nevartoja tik mažiau, nei kas antras vaikas. Nors palyginus su ankstesnių metų tyrimų duomenimis [6], kai buvo nusta- 
tyta, kad saldumynus kasdien vartojo kas antras 6-7 klasių mokinys, saldumynų vartojimo dažnumas mažèja. Vaikų, atsakiusių, kad vartoja saldumynus (saldainius, šokoladą, vaflius su pertepu, pyragaičius su kremu ar glaistu, tortus ir kt.) kasdien (vieną ir kelis kartus per dieną) $2019 \mathrm{~m}$. buvo 39,3 proc., iš kurių kas ketvirtas nurode, kad saldumynus valgo kartą, o beveik kas septintas - kelis kartus per dieną. Nepriklausomai nuo vaikų amžiaus, lyties bei gyvenamosios vietos, kas ketvirtas mokyklinio amžiaus vaikas atsakè, kad kasdien (vieną ir kelis kartus per dieną) geria įvairius gazuotus ir (ar) saldžiuosius gerimus (Pepsi, Coca cola, Fanta, Sprite ir pan.). Kitų straipsnių autoriai taip pat nurodo, kad nemaža dalis vaikų vartoja saldžiuosius gèrimus $[4,7,12]$.

Stebima tendencija, kad dažniausiai sveikatai nepalankius ìvairius gazuotus ir (ar) saldžiuosius gèrimus, kaip ir saldumynus, bei bulvių, kukurūzų ar kitokius traškučius, kitus riebaluose virtus, skrudintus ar spragintus gaminius vartoja 5-8 kl. mokiniai - 11-14 m. amžiaus paaugliai. Didžioji dalis (90,5 proc.) vaikų atsakè, kad energinių gèrimų arba nevartoja, arba juos vartoja tik labai retai (kelis kartus per mènesị), tačiau kas dešimtas 9-12 klasių mokinys atsakè, kad kelis kartus per savaitę vartoja energinius gérimus. Nors ir nedaug, tačiau dalis $(4,2$ proc. visų vaikų) vaikų nurodè, kad energinius gèrimus vartoja dažnai - kasdien ir kelis kartus per dieną.

Nustatyti tam tikri vaikų mitybos ịpročių skirtumai, priklausomai nuo amžiaus, lyties ir gyvenamosios vietos. Panašius skirtumus pateikia ir kitų straipsnių autoriai [3-12, 17-19]. Atlikto tyrimo duomenimis, jaunesni vaikai, lyginant su vyresniais, o berniukai, lyginant su mergaitemis, dažniau valgo 4 ir daugiau kartų per parą, dažniau pusryčiauja bei valgo karštus pietus mokykloje, dažniau vartoja pieną ir pieno produktus, mèsą ir jos produktus. Jaunesni vaikai, lyginant su vyresniais, dažniau valgo daržoves (išskyrus bulves), vaisius ir uogas, žuvị ir jos produktus. Daržoves šiek tiek dažniau valgo mergaitės, negu berniukai, ir mieste, negu kaime gyvenantys vaikai. Mieste gyvenantys vaikai dažniau pusryčiauja, vartoja pieną ir jo produktus; kaime gyvenantys vaikai dažniau valgo karštus pietus mokykloje, vartoja mésą ir jos produktus.

\section{Išvados}

1. Ne visų mokyklinio amžiaus vaikų mitybos ịpročiai atitinka sveikos mitybos rekomendacijas.

2. Visi vaikai, nepriklausomai nuo amžiaus, per mažai vartoja sveikatai palankių maisto produktų - daržovių, vaisių, uogų, žuvies ir jos gaminių.

3. Nemaža dalis vaikų, dažniausiai 11-14 metų (5-8 klasès), vis dar vartoja sveikatai nepalankius maisto produktus
- bulvių, kukurūzų ir kitus traškučius, kitus riebaluose virtus, skrudintus ar spragintus gaminius, saldumynus, geria ịvairius gazuotus ir (ar) saldžiuosius gèrimus.

\section{Literatūra}

1. Investing in children: the European child and adolescent strategy 2015-2020. EUR/RC64/12 2014;140440:20.

2. European food and nutrition action plan 2015-2020. EUR/ RC64/14 2014;144026:19.

3. Bartkevičiūtė R., Barzda A. Mokyklinio amžiaus vaikų sveikos mitybos skatinimas. Metodinè informacinė medžiaga visuomenès sveikatos biurų specialistams. Sveikatos mokymo ir ligų prevencijos centras, 2014.

http://www.smlpc.lt/media/file/Metodine \%20medziaga/2014\%20MOK\%20rekom\%20mitybos\%20skatinimas $\% 20$ 2015\%2001\%2012.pdf

4. Mocevičienè R. Lietuvos moksleivių mityba ir jos socialiniaiekonominiai netolygumai. Daktaro disertacija, 2015. https:// repository.lsmuni.lt/handle/1/60315

5. Strukčinskienė B., Strazdienė N., Griškonis S. Pradinių klasių mokinių mitybos namuose ir mokykloje ypatumai. Sveikatos mokslai, 2015; 25(4):5-9.

https://doi.org/10.5200/sm-hs.2015.063

6. Bendrojo lavinimo mokyklų 6-7 klasių mokinių mitybos ịpročių ir fizinio aktyvumo ịgūdžių tyrimo (2016) ataskaita. Sveikatos mokymo ir ligu prevencijos centras, 2016. http://smlpc.lt/ media/image/Naujienoms/2017\%20metai/Lankstukai/_2016_ ATASKAITA_Sveikatiadai_GA.pdf

7. Žandaras Ž., Stukas R. Pradinių klasių mokinių mitybos ypatumų pokyčiai. Palyginamasis 2010 ir 2014 metų tyrimas. Sveikatos mokslai, 2017;27(1):17-21.

https://doi.org/10.5200/sm-hs.2017.004

8. Žandaras Ž., Stukas R. Sveikatai nepalankių maisto produktų ir gèrimų vartojimo paplitimas tarp pradinių klasių mokinių. Visuomenès sveikata, 2017;1(76):68-74.

9. Bartkevičiūtè R., Kranauskas A., Stukas R., Barzda A. Mokyklinio amžiaus vaikų daug cukraus turinčių maisto produktų bei gèrimų suvartojimo tyrimas. Sveikatos mokslai, 2018; 28(3):24-29.

https://doi.org/10.5200/sm-hs.2018.035

10. Doichinova L, Bakardjiev P, Peneva M. Assessment of food habits in children aged 6-12 years and the risk of caries. Biotechnol\&Biotechnol Equip 2015;29(1):200-204. https://doi.org/10.1080/13102818.2014.989180

11. O'Leary E, Buosi W, Crabtree D, Horgan G, Fyfe C, Johnstone AM. Sugar intake in Scottish children (Full4Health Study). Proc Nutr Soc 2017;76 (OCE3):E66. https://doi.org/10.1017/S0029665117001392

12. Figueiredo RAO, Viljakainen J, Viljakainen $\mathrm{H}$, et al. Identifying eating habits in Finnish children: a cross-sectional study. BMC Public Health 2019;19(1):312. https://bmcpublichealth.biomedcentral.com/articles/10.1186/s12889-019-6603-x\#citeas 
https://doi.org/10.1186/s12889-019-6603-x

13. Europos Sajungos Tarybos išvados dèl maisto produktų gerinimo. 2016/C 269/04.

14. Lietuvos Respublikos Seimo 2014 m. birželio 26 d. nutarimas Nr. XII-964 "Dèl Lietuvos sveikatos 2014-2025 metų strategijos patvirtinimo".

15. Lietuvos Respublikos Vyriausybès 2015 m. gruodžio 9 d. nutarimas Nr. 1291 "Dèl Nacionalinès visuomenès sveikatos priežiūros 2016-2023 metų plètros programos patvirtinimo".

16. Sveikatos apsaugos ministro $2011 \mathrm{~m}$. lapkričio $11 \mathrm{~d}$. ịsakymas Nr. V-964 "Dèl maitinimo organizavimo ikimokyklinio ugdymo, bendrojo ugdymo mokyklose ir vaikų socialinès globos istaigose tvarkos aprašo patvirtinimo".

17. Health behaviour in school-aged children (HBSC) study: international report from the 2013/2014 survey.

http:/www.euro.who.int/_data/assets/pdf_file/0003/303438/ HSBC-No.7-Growing-up-unequal-Full-Report.pdf?ua=1

18. Mokyklinio amžiaus vaikų gyvensena. 2016 m. rodiklių suvestinè - ataskaita. Higienos institutas, 2016.

http://www.hi.lt/uploads/pdf/padaliniai/GYVENSENA/ Gyvensena_leidinys.pdf

19. Lietuvos mokinių sveikatos ir gyvensenos pokyčiai. $2018 \mathrm{~m}$. Lietuvos mokinių sveikatos ir gyvensenos tyrimo (HBSC) rezultatų pristatymas.

http://www.svietimonaujienos.lt/lietuvos-mokiniu-sveikatosir-gyvensenos-pokyciai/

\section{STUDY AND EVALUATION OF NUTRITION}

HABITS OF SCHOOL AGE CHILDREN

\section{R. Bartkevičiūtė, G. Bulotaitė, R. Stukas, M. Skardžiūtė, I. Nakutavičiūtè, A. Barzda}

Keywords: schoolchildren, eating habits, food products, beverages.

Summary

Aim. To assess and evaluate nutrition habits of school age children who attend Lithuanian general education schools.

Methods. The survey was carried out in September-December of 2018 . 4623 children ( $1^{\text {st }}-12^{\text {th }}$ grades $)$ who attend general education schools were surveyed. Questionnaires were anonymous, children were not asked to write their first or last names. Statisti- cal analysis was performed using the statistical analysis tool SPSS (version 18.0). The difference was considered statistically significant when $\mathrm{p} \leq 0.05$.

Results. Survey results showed that only $41 \%$ of all school age children eat 4-5 times per day, only two thirds eat breakfast every day and only half of the children eat hot lunch in school. It was discovered that children consume vegetables almost as frequently as fruits and berries - only two thirds of children consume vegetables, fruits and berries every day. $71.3 \%$ of children consume meat and meat products every day, $65.8 \%$ - milk and dairy products. However, $64.9 \%$ of children consume fish and fish products only a few times a month or do not consume it at all. $19.9 \%$ children consume potates, corn and other kinds of chips and other fried or puffed products every day. $39.3 \%$ of children consume sweets and $23.5 \%$ consume sugar-sweetened beverages everyday. $90.5 \%$ of children do not consume energy drinks or consume them few times a month.

Younger children, compared to older, and boys, compared to girls, more frequently eat 4 or more times a day, more frequently eat breakfast and hot lunch in school. Moreover, they more frequently consume milk and dairy products, meat and meat products. Younger children also more frequently eat vegetables (except potatoes), fruits, berries, fish and fish products. Girls and children living in cities consume vegetables slightly more frequently than boys and children living in rural areas. Children living in cities also more frequently eat breakfast and consume meat and dairy products. Children living in rural areas more frequently eat hot lunch in school and consume meat and meat products.

Conclusions. Not all school age children's nutrition habits comply with healthy nutrition recommendations. All children consume not enough beneficial for health products - vegetables, fruits, berries, fish and fish products. Quite large proportion of children still consume products that are not beneficial for health - potato, corn and other kinds of chips and other fried or puffed products, sweets and sugar-sweetened beverages. Children aged 11-14 (5-8 grade) consume these not beneficial for health products most frequently.

Correspondence to: roma.bartkeviciute@smlpc.lt

Gauta 2020-01-06 